\title{
Water Bodies Quality along Paddy Field in Karang Ploso Sub District, Malang City, Indonesia
}

\author{
Kiki Gustinasari ${ }^{1, *}$, Joni Hermana ${ }^{1}$, and Ellina S. Pandebesie ${ }^{1}$ \\ ${ }^{1}$ Department of Environmental Engineering, Faculty of Civil, Environmental, and Geo Engineering, Sepuluh \\ Nopember Institute of Technology, Surabaya -Indonesia
}

\begin{abstract}
Agricultural activities cannot be separated from the use of agrochemical, both chemical fertilizer and pesticides. As the largest water user sector, agricultural activities are a source of water pollution. This study was carried out in Brantas' upper stream along paddy fields, Karangploso Subdistrict, Malang District. The river water samples were collected along the paddy field. The samples were collected when ahead of the harvest season. During the harvest season, pesticides were not sprayed but the concentration of pesticides in the river is quite high. Because no studies have previously measured Organochlorine Pesticide levels in the river along paddy fields, this study is an important contribution to the knowledge of organochlorine contaminants present in surface water in Karang Ploso Subdistrict. The river water has a high concentration of organochlorine pesticides of $400.000 \mathrm{ppt}$, Total Dissolved Solids (TDS) of 226,8 mg/L, Biological Oxygen Demand (BOD) of 10,2 mg/L, Dissolved Oxygen (DO) of 3,8 $\mathrm{mg} / \mathrm{L}$, Chemical Oxygen Demand (COD) of $36,4 \mathrm{mg} / \mathrm{L}$, total phosphate (PO4-) of 0,2 mg/L, nitrate (NO3N) of $0,7 \mathrm{mg} / \mathrm{L}$, Total Suspended Solids (TSS) of $53 \mathrm{mg} / \mathrm{L}$, and potential of Hydrogen $(\mathrm{pH})$ in lab and field of 8 and 7,08 , respectively.
\end{abstract}

Keywords: pesticides; water pollution; agriculture; runoff; toxicity.

\section{Introduction}

Agriculture is the sector that uses the most water in its activities, especially for irrigation. About $70 \%$ even in some cases up to $90 \%$ of the world's water needs are used for irrigation [1]. As the largest water user sector, agricultural activities become a source of water pollutants. Pollutants are in the form of residues of agrochemical materials such as chemical fertilizers and pesticides on runoff (runoff) to the water body. Pesticides have become an important part of agriculture to protect plants and livestock from pest infestations and reduction in yields for decades [2]. Pesticides are used by farmers to increase productivity. A pesticide is a joint term that includes all chemicals used to kill or control pests. In agriculture, this includes herbicides (weeds), insecticides (insects), fungicides (fungi), nematocides (nematodes), and rodenticides (vertebrate poisons). The importance of agricultural pesticides in developing countries is undeniable [3].

Pesticides are an important part of agriculture to control various types of weeds, insects, and fungi $[4,5]$. Pesticides from runoff resistance can contaminate surface water and soil [4] According to Suprapti [6], the content of pesticides in the aquatic environment can result in poisoning and death in fish and another aquatic biota. Poisoning can cause abnormalities in growth and changes in behavior and form so that the development of the population is hampered.

The organochlorine pesticides (OCs) are synthetic pesticides that are widely used throughout the world [5, 7]. Organochlorines (OCs) are the most hazardous class of pesticides. Their effluents discharged into the water bodies contain an extremely high concentration of OCs which ultimately causes environmental concern [8]. Organochlorine pesticides belong to the group of chlorinated hydrocarbons, which have wide applications in the chemical industry and agriculture. These compounds are known for being very stable in the environment, high toxicity, slow degradation, and bioaccumulation.

Monitoring data for pesticides are generally poor in much of the world and especially in developing countries. Whereas, according to [9] monitoring of pesticide residues in the river is an important source of information that describes the current state of environmental pollution. Karang Ploso Subdistrict has rice fields with an area of 1,393,900 ha. Agriculture in Karangploso Subdistrict is conventional with big use of pesticides and chemicals, concentrated in rice. This study determined the characteristics include the residue of organochlorine pesticides in water samples collected in Brantas upper stream, Karangploso Subdistrict, Malang District. This paper also presents the pathways

\footnotetext{
* Corresponding author: gustinasari.kiki@gmail.com
} 
of organochlorine pesticides and the impacts to water bodies.

\section{Materials and Methods}

\subsection{Sampling points}

Water samples were collected at 5 sampling sites along with the paddy fields in Brantas upper stream Karangploso Subdistrict, Malang District (Fig. 1.). The coordinates of the sampling points were presented in Table 1. The bottles that used were from the glass with 2,5 L volume. The standard method that used to be the guideline of sampling is PacifiCorp FERC No. 2082. So that there was no reaction with the light, the bottles were wrapped with black plastic. The point of sampling was in the middle of water bodies The time was during the dry season. At that time was ahead of the harvest season. The characteristic of runoff when harvest season and planting season were the difference.

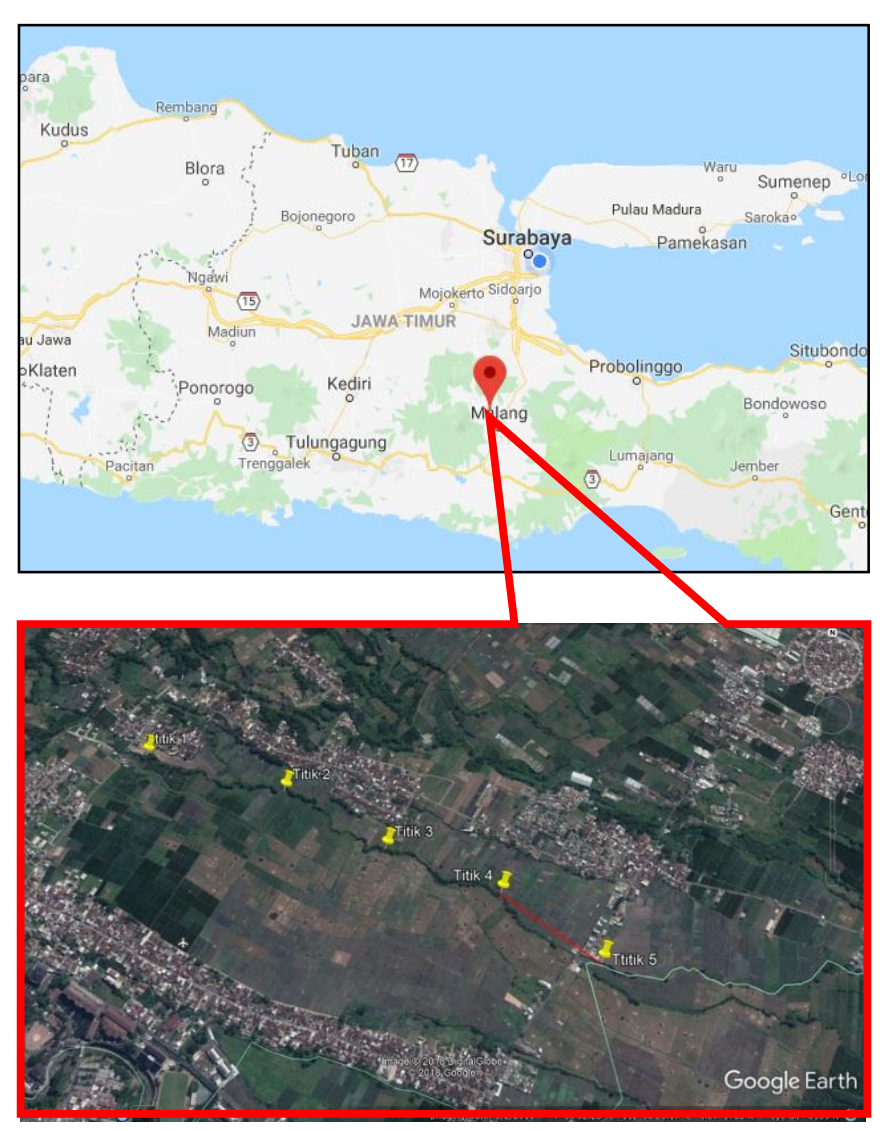

Fig. 1. The 5 sites of water sampling

Table 1. The coordinate of sampling points

\begin{tabular}{|c|c|}
\hline Station & Coordinate \\
\hline 1 & $7^{\circ} 54^{\prime} 49.5^{\prime \prime} \mathrm{S} 112^{\circ} 35^{\prime} 54.3^{\prime \prime} \mathrm{E}$ \\
\hline 2 & $7^{\circ} 54^{\prime} 53.3^{\prime \prime} \mathrm{S} 112^{\circ} 36^{\prime} 09.7^{\prime \prime} \mathrm{E}$ \\
\hline 3 & $7^{\circ} 54^{\prime} 59.6^{\prime \prime} \mathrm{S} 112^{\circ} 36^{\prime} 18.9^{\prime \prime} \mathrm{E}$ \\
\hline 4 & $7^{\circ} 55^{\prime} 04.0^{\prime \prime} \mathrm{S} 112^{\circ} 36^{\prime} 29.7^{\prime \prime} \mathrm{E}$ \\
\hline 5 & $7^{\circ} 55^{\prime} 10.4^{\prime \prime} \mathrm{S} 112^{\circ} 36^{\prime} 38.4^{\prime \prime} \mathrm{E}$ \\
\hline
\end{tabular}

\subsection{Samples analysis}

The measured physical characteristics were Total Dissolved Solids (TDS) and Total Suspended Solid (TSS). The measured chemical characteristics were Organochlorine pesticides residue, Biological Oxygen Demand (BOD), Dissolved Oxygen (DO), Chemical Oxygen Demand (COD), total phosphate $\left(\mathrm{PO}_{4}-\right)$, nitrate $\left(\mathrm{NO}_{3}-\mathrm{N}\right)$, and potential of Hydrogen $(\mathrm{pH})$.

The TDS was determined using conductometry based on the standard method of UP.IK.21.01.06. The TSS was determined using spectrophotometry based on standard methods of UP.IK.21.01.07. The Organochlorine pesticides residue was determined using Gas Chromatography (GC) based on USEPA SW 846 Method 8270D; 3510C (1998; 1996). The BOD 5 and COD were determined based on SNI 6989.72-2009 and SNI 6989.2-2009, respectively. The DO was determined based on SNI 06-6989.14-2004. Total phosphate was determined based on APHA Ed. 22nd 4500-P. B\&E2012. Nitrate was determined based on APHA Ed.22nd 4500-NO3.E-2012.

\section{Results and Discussion}

\subsection{Characteristics of water bodies along paddy fields}

The average of physical and chemical characteristics of water bodies along paddy fields are shown in Table 2 .

Table 2. Physic chemical characteristics of water bodies along the paddy fields

\begin{tabular}{|r|l|c|c|c|}
\hline No & \multicolumn{1}{|c|}{ Parameter } & Unit & Result & Standards \\
\hline 1 & $\begin{array}{l}\text { Total Dissolved } \\
\text { Solids (TDS) }\end{array}$ & $\mathrm{mg} / \mathrm{L}$ & 226,8 & $1000^{*}$ \\
\hline 2 & $\begin{array}{l}\text { Biologycal } \\
\text { Oxygen Demand } \\
\left(\mathrm{BOD}_{5}\right)\end{array}$ & $\mathrm{mg} / \mathrm{L}$ & 10,2 & $3^{*}$ \\
\hline 3 & $\begin{array}{l}\text { Dissolved oxygen } \\
(\mathrm{DO})\end{array}$ & $\mathrm{mg} / \mathrm{L}$ & 3,8 & $4^{*}$ \\
\hline 4 & $\begin{array}{l}\text { Chemical Oxygen } \\
\text { Demand (COD) }\end{array}$ & $\mathrm{mg} / \mathrm{L}$ & 36,4 & $25^{*}$ \\
\hline 5 & $\begin{array}{l}\text { Phosphate Total } \\
(\text { PO4) }\end{array}$ & $\mathrm{mg} / \mathrm{L}$ & 0,2 & $0,2^{*}$ \\
\hline 6 & Nitrate (NO3-N) & $\mathrm{mg} / \mathrm{L}$ & 0,7 & $10^{*}$ \\
\hline 7 & $\begin{array}{l}\text { Total Suspended } \\
\text { Solid (TSS) }\end{array}$ & $\mathrm{mg} / \mathrm{L}$ & 53 & $50^{*}$ \\
\hline 8 & $\begin{array}{l}\text { Temperature } \\
(\text { Lab) }\end{array}$ & $\mathrm{o} \mathrm{C}$ & 22 & $20,7-27,7^{*}$ \\
\hline 9 & Ph (field) & - & 7,08 & $6-9 *$ \\
\hline 10 & Ph (lab) & - & 8 & $6-9 *$ \\
\hline 11 & $\begin{array}{l}\text { Organochlorine } \\
\text { pesticide residue }\end{array}$ & $\mathrm{ppt}$ & 400.000 & $100.000^{* *}$ \\
\hline
\end{tabular}

* Class quality standards II Indonesian Government Regulation No. 81 the year 2001, ** Maximum Residue Limit (MRL) from the Food and Agriculture Organization (FAO)/World Health Organization (WHO) 
Because the samples were from the Brantas upper stream, so the water quality must be around class II. Based on the result the nutrient $\mathrm{N}$ and $\mathrm{P}$ were not high because the samples were taken on harvest season. Runoff from paddy fields will bring a lot of nutrients and pesticide residues during the season of the appearance of planting and rice grains. At the time, the pollution potential of water bodies is getting higher. In contrast to pesticides, the nutrient is more easily degraded than pesticides. The residue of pesticides from the upper stream may be carried downstream.

The river flows from station 1 to station 5. Station 1 is located after settlement. Station 2 until 5 is along the paddy field. The different characteristics among station 1 to 5 could be analyzed as the effect of paddy field to water bodies. Here are some parameters with the regression that shows the relationship between the presence of a paddy field with parameters. Regression correlation is divided into six classifications. They are: 0 (no correlation); $>0-0,25$ (very low correlation); $>0,25$ - 0,5 (enough correlation); >0,5 - 0,75 (strong correlation); and $>0,75-0,99$ (very strong correlation); 1 (perfect correlation).

\subsection{Total Dissolved Solids (TDS)}

The TDS increased from station 1 to station 5. Although in station 4 it was down but in the last station it was higher. Fig. 2 shows the linear correlation with regression 0,72 (strong correlation). Water quality is correlated with the amount of TDS. TDS shows the number of inorganic salts and organic material in water [12]. When the water has a high TDS value, there are harmful contaminants in the water [12]. According to Indonesian Government Regulation No. 81 the year 2001, the value is still under a standard. It is good enough, but from the increase of TDS from station 1 to 5 indicate that the paddy field could increase the TDS value.

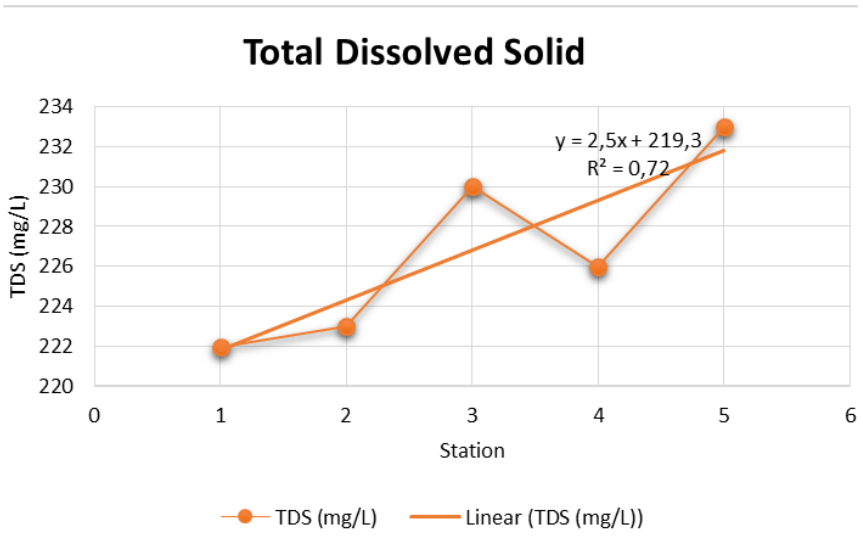

Fig. 2. The regression graphic of TDS

\subsection{Biological Oxygen Demand (BOD5)}

Fig. 3 shows the linear correlation between the presence of the paddy field and the increase of BOD. The BOD increases from station 1 to 5 , even in station 2 decrease but after this increase higher than station 1 . The regression is 0,52 , it is on the range of strong correlation. BOD is the measurement of the amount of oxygen needed to decompose organic matter in aerobic conditions [13]. Low BOD is a good indicator of good quality water, while high BOD indicates contaminated water [16]. According to Indonesian Government Regulation No. 81 the year 2001, the value is still in the above standard. The BOD should be under 3, but the average is reached $10,2 \mathrm{mg} / \mathrm{L}$.

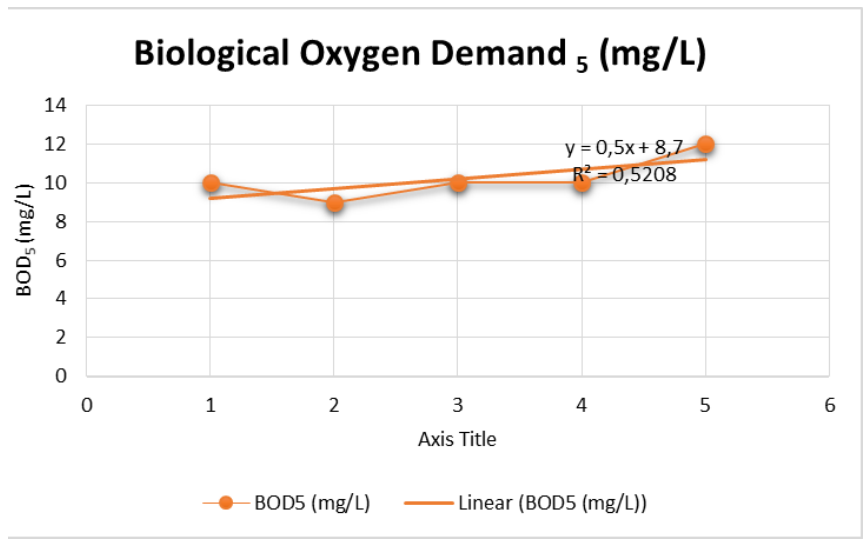

Fig. 3. The regression graphic of $\mathrm{BOD}_{5}$

\subsection{Dissolved Oxygen (DO)}

The DO decreased from station 1 to 5 (Fig. 4). The regression has a value of 0.52 , it is on the range of strong correlation. Dissolved Oxygen (DO) is defined as the amount of oxygen is dissolved in water bodies and measures health water and its ability to regulate the water balance ecosystem $[14,15]$. The DO decrease from station 1 to 5 , it is mean the water quality also decreases. The presence of the paddy field could decrease DO. Organic matter from the paddy field caused the decreasing of DO. The average DO along station is 3,8 . According to Indonesian Government Regulation No. 81 the year 2001, the DO should be the same or above $4 \mathrm{mg} / \mathrm{L}$.

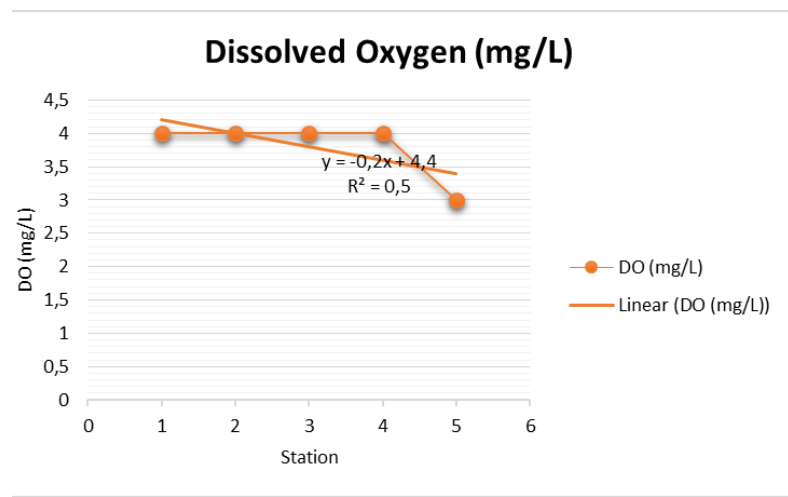

Fig. 4. The regression graphic of DO 


\subsection{Chemical Oxygen Demand (COD)}

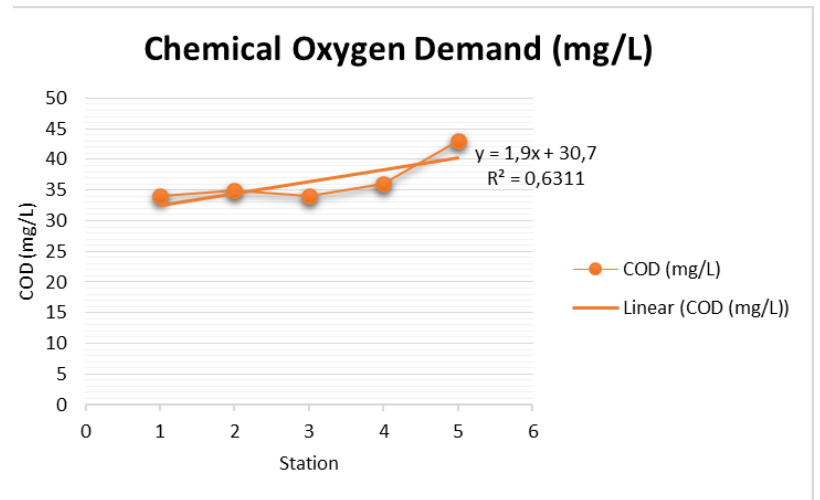

Fig. 5. The regression graphic of COD

Fig. 5 shows the linear correlation between the presence of the paddy field and the increase of COD. The regression is 0,63 , it is on the range of strong correlation. The graphic shows that the presence of the paddy field could increase the COD. The increase in COD indicates a decrease in water quality. The average of COD is above standard from Indonesian Government Regulation No. 81 the year 2001. Chemical oxygen demand is the amount of dissolved oxygen required to cause chemical oxidation of the organic material in water. Both BOD and COD are key indicators of the environmental health of a surface water supply [16;17].

\subsection{Phosphate Total $\left(\mathrm{PO}_{4}\right)$}

The phosphate shows the same value. It is $0,2 \mathrm{mg} / \mathrm{L}$ in every station. The value is the same as the standard of Indonesian Government Regulation No. 81 the year 2001. Fertilizer from the paddy field caused the amount of phosphate high. The sampling time was on harvest season. In the plant season, the phosphate may be higher than $0,2 \mathrm{mg} / \mathrm{L}$. Phosphorus is one of the most important mineral nutrients in agricultural systems, and together with nitrogen $(\mathrm{N})$, are generally the most restrictive nutrients for crop production [18]. The high nutrient can cause algal blooming, so it is important to reduce nutrient in runoff before entering water bodies.

\subsection{Nitrate $\left(\mathrm{NO}_{3}-\mathrm{N}\right)$}

The nitrate is still below the standard of Indonesian Government Regulation No. 81 the year 2001. Intensification of agricultural activities with the application of fertilizer caused unbalance nitrogen in the field. In aerobic conditions, ammonia and ammonium ion are microbially transformed from nitrite to be nitrate [19]. According to the analysis result, the nitrate from station 1 to 5 decreased (Fig. 6). It should be higher after through paddy field because of runoff from a paddy field but maybe because of in harvest season so that there was no application of fertilizer so that there was no big nitrate input to water bodies.

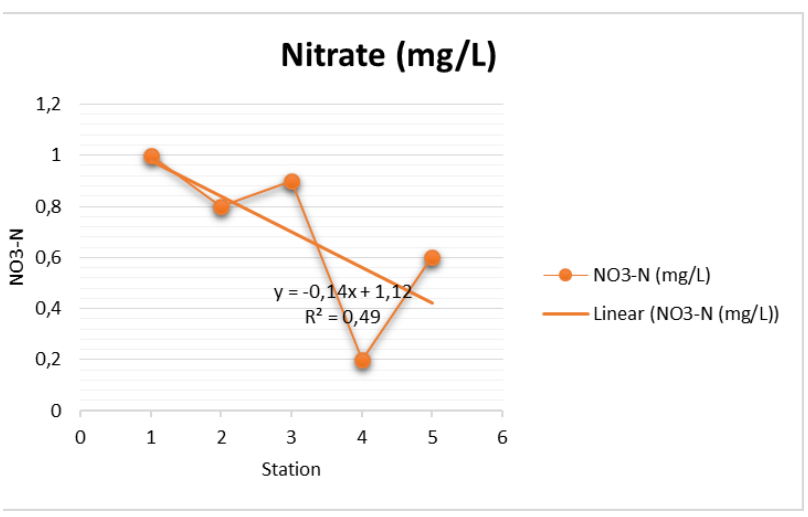

Fig. 6. The regression graphic of Nitrate

\subsection{Total Suspended Solid (TSS)}

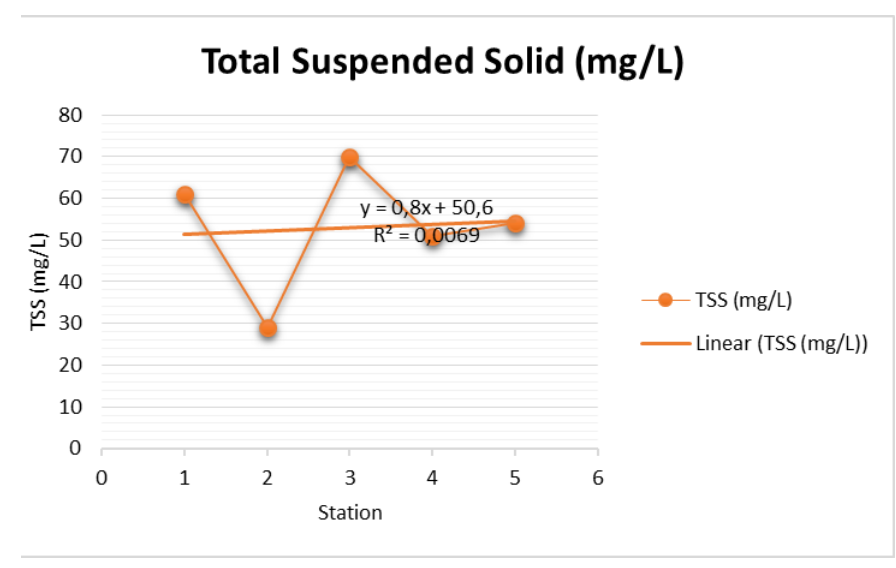

Fig. 7. The regression graphic of TSS

The correlation regression of TSS from station 1 to 5 shows very low correlation with $\mathrm{R}^{2}$ value 0,0069 (Fig. 7) From these result, we can conclude that paddy field does not give significant impact to TSS content in water bodies. But, in the rain season, the TSS may be higher because of erosion in the paddy field. The TSS average is 53, that's value is above the standard of Indonesian Government Regulation No. 81 the year 2001.

\subsection{Organochlorine Residue}

The farmland in Karang Ploso subdistrict is sloping farmland. Rapid transport of pesticide to water bodies occur when irrigation. Relevant studies have suggested OCs exhibit toxic effects to aquatic organisms, accumulate in the ecosystem due to their slow break down in the environment, potentially affect the biodiversity and pose a threat to human health $[10 ; 11]$. Extensively used OCs are persistent i.e., extremely long halflives in soil and water (up to many years), toxic, high potential to bioaccumulation, and highly resistant to microbial attack [8]. The analysis result shows that organochlorine residue is quite high, above the standard from WHO. Although the use of organochlorine is limited because of regulation from the minister of agriculture, the organochlorine residue could be from years ago because of the persistence of organochlorine. 


\section{Conclusion}

Parameters that meet the quality standards are TDS, phosphate, nitrate, temperature, and $\mathrm{pH}$. Parameters that did not meet the quality standards are BOD, DO, COD, and TSS. The river water along farmlands has a high concentration of organochlorine pesticides of 400.000 ppt. These could reduce the qualities of the Brantas River. Because of the sampling location is in the upper stream, so the pesticide may be carried out to downstream.

\section{Acknowledgment}

The authors are grateful for the financial support from the Ministry of Research and Higher Education of the Republic of Indonesia with Master leading to Ph.D. scholarship (PMDSU), which made this study to work out.

\section{References}

1. FAO, Control of Water Pollution from Agriculture, FAO Irrigation and Drainage Paper 55 (1996)

2. P. Pujiastuti, Sumardiyono, S. Mutiah, The Distribution Patterns of Wuryanti Sub-watershed Nitrogen and Phosphorus Non-Source Source Pollution to Gajah Mungkur Wonogiri Reservoir, Seminar Nasional Teknologi Kimia, Industri, dan Informasi (2015)

3. A. Özkara, D. Akyil, M. Konuk, Pesticides, Environmental Pollution, and Health, Environmental Health Risk - Hazardous Factors to Living Species, Ed. InTech (2016)

4. G.D. Gikas, Z. Vryzas, V.A. Tsihrintzis, SMetolachlor Herbicide Removal in Pilot-Scale Horizontal Subsurface Flow Constructed Wetlands, Chemical Engineering Journal 339, 108116 (2018)

5. R. Jayaraj, P. Megha, P. Sreedev, Organochlorine Pesticide, Their Toxic Effect on the Living Organism and Their Fate in the Environment, Interdiscip Toxicol 9, 90-100 (2016)

6. Suprapti, The Guidelines for Guiding the Use of Pesticides. Directorate General of Agriculture Infrastructure and Facilities, Ministry of Agriculture (2011)

7. Y. Huang, L. Xiao, F. Li, M. Xiao, D. Lin, X. Long, Z. Wu, Microbial Degradation of Pesticide Residues and an Emphasis on the Degradation of Cypermethrin and 3- phenoxy Benzoic Acid: A Review, Molecules 23, 2313 (2018)

8. M. Rani, U. Shanker, V. Jassal, Recent Strategies for Removal and Degradation of Persistent \& Toxic Organochlorine Pesticides Using Nanoparticles: A Review, J. Environ. Manage. 2018, 208-222 (2018)
9. H. Dahshan, A.M. Megahed, A.M.M. Abd-Elall, M.A.-G. Abd-El-Kader, E. Nabawy, M.H. Elbana, Monitoring of Pesticides Water Pollution-The Egyptian River Nile, J. Environ. Health Sci. Eng. 14 (2016)

10. S. Hua, J.L. Gong, G.M. Zeng, F.B. Yao, M. Guo, X.M. Ou, Remediation of Organochlorine Pesticides Contaminated Lake Sediment Using Activated Carbon and Carbon Nanotubes, Chemosphere 177, 65-76 (2017)

11. C. Temoka, J. Wang, Y. Bi, D. Deyerling, G. Pfister, B. Henkelmann, K.W. Schramm, Concentrations and Mass fluxes Estimation of Organochlorine Pesticides in Three Gorges Reservoir with Virtual Organisms Using in Situ PRC-Based Sampling Rate, Chemosphere 144, 1521-1529 (2016)

12. R. Islam et al., Assessment of $p H$ and Total Dissolved Substances (TDS) in the Commercially Available Bottled Drinking Water, 6, 35-40

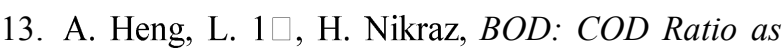
an Indicator for River Pollution

14. I. Mohammed, F. Othman, A.I.N. Ibrahim, M.E. Alaa-Eldin, R.M. Yunus, Assessment of Water Quality Parameters Using Multivariate Analysis for Klang River Basin, Malaysia, Enviro Monit Assess 187, 4182 (2015)

15. J. Synder, Dissolved Oxygen (2007)

16. J.J. Mocuba A.M. Hoguane, Dissolved Oxygen and Biochemical Oxygen Demand in the Waters Close to the Quelimane Sewage Discharge (2010)

17. M. Shukla, S. Arya, S. Agarwal, Study of Correlation Coefficient for Physico-Chemical Parameter to Assess the Water Quality of River Ganga At Kanpur, India, Int. J. Innov. Res. Sci. 6, 17164-17170 (2017)

18. M.R. Hart, B.F. Quin, M.L. Nguyen, Phosphorus Runoff from Agricultural Land and Direct Fertilizer Effects, J. Environ. Qual. 33(6), 1954 (2010)

19. A.J.P. Smolders, E.C.H.E.T. Lucassen, R. Bobbink, J.G.M. Roelofs, L.P.M. Lamers, How Nitrate Leaching from Agricultural Lands Provokes Phosphate Eutrophication in Groundwater Fed Wetlands: The Sulphur Bridge, Biogeochemistry 98(1-3), 1-7 (2010) 